\title{
A single center experience: physician related diagnostic delay and demographic and clinical differences between patients with ankylosing spondylitis and non-radiographic axial spondyloarthritis
}

\author{
FIRDEVS ULUTAȘ ${ }^{1}$, VELİ ÇOBANKARA ${ }^{1}$, HANDE SSENOL ${ }^{2}$, UĞUR KARASU ${ }^{1}$, SERDAR KAYMAZ ${ }^{1}$, \\ CANAN ALBAYRAK YAŞAR ${ }^{1}$, ZEYNEP DÜNDAR ÖK $^{1}$, MURAT YİĞİT ${ }^{1}$
}

\footnotetext{
1: Division of Rheumatology, Department of Internal Medicine, Pamukkale University Faculty of Medicine, Denizli, Turkey

${ }^{2}$ Department of Biostatistics, Pamukkale University Faculty of Medicine, Denizli, Turkey
}

\begin{abstract}
Background. A large number of comparative studies have been conducted for ankylosing spondylitis (AS) and non-radiographic axial spondyloarthritis (nr-axSpA), including disease burden, treatment modalities and patient characteristics. The aim of this study was to compare physician related diagnostic delay time between patients with AS and nr-axSpA.

Methods. In our retrospective study we included 266 patients with axSpA. Patients were classified into two subgroups, AS and nr-axSpA. The time from back pain onset until diagnosis of axSpA was defined as the diagnostic delay. The first specialist referred to and the first diagnosis for each patient was noted in detail. Patient characteristics, clinical manifestations and laboratory and imaging results at diagnosis were also compared between subgroups.

Results. The diagnostic delay time was significantly longer for AS patients $[6 \pm 8.14$ years vs $1.62 \pm 2.54$ years]. $40.9 \%$ of all patients were initially consulted by specialists in physical therapy and rehabilitation, followed by $29.7 \%$ consulted by a neurosurgeon and $19.9 \%$ by a rheumatologist. The most common initial diagnosis was fibromyalgia, 52.6\% (140), followed by ankylosing spondylitis, $28.9 \%$ (77), and lumbar disc hernia, $12.7 \%$ (34).

Conclusion. The vast majority of patients were initially evaluated by healthcare providers other than rheumatologists and mostly diagnosed with fibromyalgia. Efforts to increase awareness and to educate first healthcare providers may shorten the diagnostic delay time.
\end{abstract}

Key words: ankylosing spondylitis, non-radiographic axial spondyloarthritis, axial spondyloarthritis, fibromyalgia, differential diagnosis.

\section{INTRODUCTION}

Axial spondyloarthritis (axSpA) is a common chronic inflammatory rheumatologic disease. From the results of numerous community-based studies, its prevalence is approximately $1 \%$ of the population [1]. Patients with axSpA are identified as ankylosing spondylitis (AS) or non-radiographic axial spondyloarthritis (nr-axSpA), distinguished by the presence or absence of definitive sacroiliitis on plain radiographs [2]. 5-10\% of nr-axSpA patients have been shown to develop AS within 2 years, and $20 \%$ of them within 5 years [3]. It is also well known that the progression occurs more frequently in male patients with active sacroiliitis, positive HLA B-27 and high c-reactive protein (CRP) values at diagnosis [4].

Delayed diagnosis and inadequate treatment lead to structural damage, irreversible loss of spinal mobility and poor quality of life in patients with axSpA [5]. Currently, it is thought that AS and nr-
axSpA are two different clinical entities in the same spectrum, only differing in terms of chronicity [6]. Therefore, for early diagnosis and timely treatment, it is very important to know the similarities and differences between these two clinical entities.

Recently, many studies have compared patients with AS and nr-axSpA in terms of patient characteristics, disease burden, activity criteria and treatment modalities. The aim of this study was to compare diagnostic delay time, physician related factors (specialists consulted initially and first diagnoses) in addition to all of the above parameters between patients with AS or nr-axSpA.

\section{MATERIAL AND METHODS}

Patient selection and definition of axial
spondyloarthritis
We evaluated retrospectively the medical
records of 360 patients in total between


December 2019 and January 2020. Overall, 94 of the patients were excluded due to insufficient data and irregular follow-up and 266 patients diagnosed with axSpA between January 1999 and November 2019 were included. All of them were diagnosed with axSpA in our tertiary single center and followed up regularly up to the present in the rheumatology department of internal medicine at Pamukkale University, Denizli. Patients that were diagnosed with axSpA before coming to our center were excluded.

All of the patients fulfilled the 2009 axspa classification criteria of the assessment of spondylo arthritis international society (asas) [7]. all of them had inflammatory back pain initially. sij $x$-rays were present for all axspa cases. patients with axspa were classified into two subgroups as as or nr-axspa, distinguished by the presence or absence of definitive sacroiliitis and structural damage on the baseline plain radiographs. all of the as cases were diagnosed based upon the modified new york criteria regardless of the presence of hla b-27 [8]. patients with nr-axspa that had no definitive sij changes on plain $\mathrm{x}$-rays underwent mri imaging. only two patients in the nr-axspa group were diagnosed without imaging with hla b-27 positivity. all of the pelvic $x$-ray and mri scans of the sacroiliac joints were evaluated by the same experienced rheumatologist, who was blinded to the laboratory results and clinical presentations. hip involvement of patients was noted as current or ever by the same experienced rheumatologist. also, mri findings of sacroiliac joints (sijs) were grouped as subchondral bone marrow edema and/or degenerative fatty changes. an additional consultant radiologist was not invited into this study. recent studies have shown that rheumatologists have similar mri interpretations of si joints in spa patients as expert radiologists without any interobserver variation [9].

\section{Definition of disease duration and delay of diagnosis}

The first specialist who evaluated the patient and the first diagnosis for each patient before the correct diagnosis were noted. The information notes containing detailed anamnesis and physical examination for each patient were examined in detail. The time from diagnosis to the present was defined as the disease duration. The time from back pain onset until diagnosis of axSpA was defined as the diagnostic delay.

\section{Outcome measures}

Patient characteristics (gender, age, disease duration, diagnostic delay, specialists initially referred to and first diagnosis), clinical manifestations, laboratory results [c-reactive protein (CRP), erythrocyte sedimentation rate (ESR), specified as $\mathrm{mm} /$ hour and $\mathrm{mg} / \mathrm{dl}$, respectively] and imaging results [X-ray, magnetic resonance imaging (MRI)], Bath Ankylosing Spondylitis Disease Activity Index (BASDAI) scores at diagnosis and treatment modalities were analyzed retrospectively and compared between the two subgroups of AS and nr-axSpA.

All of the patients presented with inflammatory back pain (IBP) initially. Other extra-articular manifestations including uveitis and inflammatory bowel disease, or presence or absence of peripheral arthritis at diagnosis were noted in detail. In the follow-up, information on medication use and drugs were collected from prescriptions in the medical charts. Human Leukocyte Antigen B-27 (HLA B-27) status was noted as positive, negative or not available.

Ethics approval and consent to participate

Local ethical committee approval was obtained from the Ethics Committee of Pamukkale University Faculty of Medicine with the decision dated $15 / 10 / 2019$ and numbered 15. Written informed consent was not obtained for each patient due to the retrospective nature of the current study.

\section{Statistical analysis}

The medical records of patients were obtained using the Probel data system. Analyses of the study were performed with SPSS (IBM Corp. Released 2017. IBM SPSS Statistics for Windows, Version25.0, Armonk, NY: IBM Corp.) and statistical significance was determined as p:0.05. In the study, the suitability of continuous variables to normal distribution was examined by Shapiro-Wilk and Kolmogorov Smirnov Tests. Continuous variables were expressed as mean \pm standard deviation and median (interquartile range - IQR), and categorical variables were expressed as number and percent. For independent group comparisons, Mann-Whitney U test was used since parametric test assumptions were not provided. Differences between categorical variables were evaluated using chi-square test. 


\section{RESULTS}

Overall 266 axSpA patients (60\% male) were classified into two subgroups, including $213(80.1 \%)$ patients with AS and $53(19.9 \%)$ patients with nraxSpA. $143(67.1 \%)$ patients in the AS group and 18 $(33.9 \%)$ patients in the nr-axSpA group were male [p:0.0001], Table 1. The mean age of patients was 44 (23-77) in the AS group and $37(18-58)$ in the
nr-axSpA group. In patients with AS compared to nr-axSpA, longer disease duration $[10.55 \pm 9.68$; $3.61 \pm 3.67$; p:0.0001] was also seen (Table 1). At diagnosis, higher ESR values [29.63 \pm 16.44 $\mathrm{mm} /$ hour; $23.17 \pm 12.59 \mathrm{~mm} /$ hour; p:0.011], higher CRP values $[1.34 \pm 1.57 \mathrm{mg} / \mathrm{dl} ; 0.66 \pm 0.67 \mathrm{mg} / \mathrm{dl}$; p:0.004] and higher BASDAI scores [4.49 \pm 2.52 ; $3.08 \pm 1.4$; p:0.002] were seen in the AS group compared to the nr-axSpA group.

\section{Table 1}

Comparison of different parameters between AS and nr-axSpA subgroups

\begin{tabular}{|c|c|c|c|c|}
\hline & All patients & AS & nr-axSpA & pvalue \\
\hline $\begin{array}{l}\text { Gender (male) } \\
\mathrm{n}(\%)\end{array}$ & $161(60.5 \%)$ & $143(67.1 \%)$ & $18(33.9 \%)$ & p:0.0001* \\
\hline $\begin{array}{l}\text { Disease duration (median } \pm \text { Standard } \\
\text { deviation) }\end{array}$ & $7.08 \pm 6.67$ & $10.55 \pm 9,68$ & $3.61 \pm 3.67$ & $\mathrm{p}: 0.0001^{*}$ \\
\hline $\begin{array}{l}\text { Diagnostic delay (median } \pm \text { Standard } \\
\text { deviation) }\end{array}$ & $3.81 \pm 5.34$ & $6 \pm 8.14$ & $1.62 \pm 2.54$ & $\mathrm{p}: 0.0001^{*}$ \\
\hline Number of specialists [mean (min - max)] & $2(1-4)$ & $2(1-4)$ & $1(1-4)$ & p:0.105 \\
\hline Current peripheral arthritis n $(\%)$ & $41(15.4 \%)$ & $34(15.9 \%)$ & $7(13.2 \%)$ & p:0.619 \\
\hline Current uveitis n (\%) & $17(6.3 \%)$ & $17(7.9 \%)$ & $0(0 \%)$ & $\mathrm{p}: 0.028^{*}$ \\
\hline $\begin{array}{l}\text { Current inflammatory bowel disease } \\
\mathrm{n}(\%)\end{array}$ & $12(4.5 \%)$ & $11(5.1 \%)$ & $1(1.8 \%)$ & p:0.344 \\
\hline $\begin{array}{l}\text { HLA B-27 positive and negative, } \\
\text { respectively } \mathrm{n}(\%)\end{array}$ & $\begin{array}{l}85(31.9 \%), 110 \\
(41.3 \%)\end{array}$ & $\begin{array}{l}72(33.8 \%), 77 \\
(36.1 \%)\end{array}$ & $\begin{array}{l}13(24.5 \%), 33 \\
(62.2 \%)\end{array}$ & $\mathrm{p}: 0.002 *$ \\
\hline $\begin{array}{l}\text { MRI (subchondral bone marrow edema) } \\
\mathrm{n}(\%)\end{array}$ & $71(26.6 \%)$ & $36(16.9 \%)$ & $35(66 \%)$ & p: $0.0001^{*}$ \\
\hline Current hip involvement $\mathrm{n}(\%)$ & $28(10.5 \%)$ & $28(13.2 \%)$ & $0(0 \%)$ & $\mathrm{p}: 0.005^{*}$ \\
\hline BASDAI (median \pm Standard deviation) & $3.78 \pm 1.96$ & $4.49 \pm 2.52$ & $3.08 \pm 1.4$ & $\mathrm{p}: 0.002^{*}$ \\
\hline \multicolumn{5}{|l|}{ Treatment modalities $\mathrm{n}(\%)$} \\
\hline $\begin{array}{l}\text { NSAIDs } \\
\text { DMARDs } \\
\text { Biologics }\end{array}$ & $\begin{array}{l}46(17.2 \%) \\
44(16.5 \%) \\
176(66.1 \%)\end{array}$ & $\begin{array}{l}22(10.3 \%) \\
30(14 \%) \\
161(75.5 \%)\end{array}$ & $\begin{array}{l}24(45.2 \%) \\
14(26.4 \%) \\
15(28.3 \%)\end{array}$ & $\mathrm{p}: 0.0001 *$ \\
\hline \multicolumn{5}{|l|}{ First admission outpatient clinics n (\%) } \\
\hline $\begin{array}{l}\text { Physical therapy rehabilitation } \\
\text { Neurosurgery } \\
\text { Rheumatology } \\
\text { Orthopedics } \\
\text { Others }\end{array}$ & $\begin{array}{l}109(40.9 \%) \\
79(29.7 \%) \\
53(19.9 \%) \\
10(3.7 \%) \\
15(5.5 \%)\end{array}$ & $\begin{array}{l}81(38 \%) \\
64(30 \%) \\
44(20.6 \%) \\
9(4.2 \%) \\
15(7 \%)\end{array}$ & $\begin{array}{l}28(52.8 \%) \\
15(28 \%) \\
9(16.9 \%) \\
1(1.8 \%) \\
0(0 \%)\end{array}$ & p:0.079 \\
\hline \multicolumn{5}{|l|}{ First diagnosis n (\%) } \\
\hline $\begin{array}{l}\text { Fibromyalgia } \\
\text { Lumbar disc hernia } \\
\text { AxSpA } \\
\text { Nonspecific back pain } \\
\text { Osteoarthritis }\end{array}$ & $\begin{array}{l}140(52.6 \%) \\
34(12.7 \%) \\
77(28.9 \%) \\
12(4.5 \%) \\
3(1.1 \%)\end{array}$ & $\begin{array}{l}130(61 \%) \\
29(13.6 \%) \\
45(21.1 \%) \\
7(3.3 \%) \\
2(0.9 \%)\end{array}$ & $\begin{array}{l}10(18.8 \%) \\
5(9.4 \%) \\
32(60.3 \%) \\
5(9.4) \\
1(1.8 \%)\end{array}$ & $\mathrm{p}: 0.005^{*}$ \\
\hline
\end{tabular}

AS: ankylosing spondylitis, nr-axSpA: non-radiographic axial spondyloarthritis, HLA B-27: human leukocyte antigen B-27, BASDAI: Bath Ankylosing Spondylitis Disease Activity Index, NSAIDs: nonsteroidal anti-inflammatory drugs, DMARDs: diseasemodifying antirheumatic drugs, AxSpA: axial spondyloarthritis, p*: statistically significant 
Until the correct diagnosis, the mean number of specialists who evaluated the patients was 2 and 1 in AS and nr-axSpA groups, respectively [p:0.105]. Among 266 patients with axSpA, the mean diagnostic delay time was significantly longer in AS patients compared with nr-axSpA patients, respectively [ $6 \pm 8.14$ (year); $1.62 \pm 2.54$ (year); p:0.0001].

Patients were first evaluated by a physical therapy and rehabilitation physician, 109 (40.9\%), by a surgeon, 89 (33.4\%) (79 neurosurgery, 10 orthopedic), rheumatologist $53(19.9 \%)$, or others 15 (5.6\%) (13 internal medicine physicians, 2 general practitioners). Physicians of physical therapy and rehabilitation were more frequently seen by nr-axSpA patients than AS patients [52.8\% (28), 38\% (81), p:0.079]. The most common initial diagnosis was fibromyalgia, 140 (52.6\%), followed by axSpA, 77 (28.9\%), lumbar disc hernia, $34(12.7 \%)$, non-specific low back pain, $12(4.5 \%)$ or osteoarthritis, $3(1.1 \%)$. According to the first diagnosis, the accuracy of axSpA diagnosis was more prominent in the nr-axSpA group than the AS group $(60.3 \%$ vs $21.1 \%$, p:0.005). In contrast, a first diagnosis of fibromyalgia was more frequent in the AS group than the nr-axSpA group (61.0\% vs $18.8 \%$, p:0.005). Accuracy of axSpA diagnosis was higher for rheumatologists than physicians of physical therapy and rehabilitation and surgeons, $83.0 \%, 23.8 \%, 6.7 \%$, respectively (Table 2 ).

Treatment modalities were statistically different between patient groups (p:0.0001). The vast majority of patients were on treatments with biologic agents $(75.5 \%)$ in the AS group whereas it was only $28.3 \%$ in the nr-axSpA group. Nearly half of patients with nr-axSpA were treated with only NSAIDs.

\section{Table 2}

The first diagnoses and physicians among all of the patients (n)

\begin{tabular}{|c|c|c|c|c|c|}
\hline & & \multicolumn{4}{|l|}{ Department of physicians } \\
\hline & & $\begin{array}{l}\text { Physical Therapy } \\
\text { Rehabilitation }(n=109)\end{array}$ & Surgeons $(\mathrm{n}=89)$ & $\begin{array}{l}\text { Rheumatology } \\
(\mathrm{n}=53)\end{array}$ & Others $(n=15)$ \\
\hline \multirow{5}{*}{$\begin{array}{l}\text { First } \\
\text { Diagnosis } \\
(n=266)\end{array}$} & $\begin{array}{l}\text { Fibromyalgia } \\
(\mathrm{n}=140,52.6 \%)\end{array}$ & $83(76.2 \%)$ & $42(47.1 \%)$ & $1(1.8 \%)$ & $14(93.3 \%)$ \\
\hline & $\begin{array}{l}\text { AxSpA }(\mathrm{n}=77 \\
28.9 \%)\end{array}$ & $26(23.8 \%)$ & $6(6.7 \%)$ & $44(83.0 \%)$ & $1(6.7 \%)$ \\
\hline & $\begin{array}{l}\text { Lumbar Disc } \\
\text { Herniation } \\
(\mathrm{n}=34,12.8 \%)\end{array}$ & 0 & $33(37 \%)$ & $1(1.8 \%)$ & \\
\hline & $\begin{array}{l}\text { Nonspecific } \\
(\mathrm{n}=12,4.5 \%)\end{array}$ & 0 & $6(6.7 \%)$ & $6(11.3 \%)$ & \\
\hline & $\begin{array}{l}\text { Osteoarthritis } \\
(\mathrm{n}=3,1.1 \%)\end{array}$ & 0 & $2(2.2 \%)$ & $1(1.8 \%)$ & \\
\hline
\end{tabular}

\section{DISCUSSION}

In our study we found that the vast majority of patients were first evaluated by specialists of physical therapy and rehabilitation (FTR) and surgeons before specialists of rheumatology, and the most common initial diagnosis was fibromyalgia, accounting for $52.6 \%$ of all patients. Deodlar A. et al. has stated that only $37 \%$ of patients with AS are diagnosed by rheumatologists, the remaining $63 \%$ being diagnosed by primary care $(26 \%)$, physical therapy $(7 \%)$, orthopedic surgery (4\%) and pain clinics (4\%), and the estimated diagnostic delay for axSpA is 14 years [10]. Vedat $G$ et al. stated that the diagnostic delay was 8.1 years among 393 patients with AS. Lumbar disc hernia (LDH) was the most reported initial diagnosis for about $33 \%$ of patients, and prior diagnosis of $\mathrm{LDH}$ was a predictive factor for diagnostic delay [11]. In a community wide epidemiologic study it was shown that many patients with axSpA were referred to specialties other than rheumatologists, such as orthopedics, spine surgeons and rehabilitation medicine via primary care doctors [12]. As in the above mentioned studies, physician related factors (referral delay) and incorrect diagnoses were additional important reasons for the diagnostic delay in our study, correlating with previous literature. 
In addition, lack of validated diagnostic criteria, reliable biomarkers and limitations on physical examination of the back and SIJs lead to late recognition of axSpA. Although chronic back pain in commonly seen, the entry criteria is inflammatory back pain for axSpA. About 13\% of adults suffer from chronic back pain in the general population, and axSpA accounts for only 5\% of cases [13]. Healthcare providers other than rheumatologists may not be aware of the prevalence and importance of axSpA and may be unfamiliar with presentation of the disease as inflammatory back pain.

Although the majority of patients in both groups were evaluated by FTR specialists initially, more than half of the patients in the nr-axSpA group were diagnosed with axSpA at first admission because MRI scans were performed for the vast majority of patients (96.2\%) in this group. We believe that the presence of active sacroiliitis on MRI contributes greatly to the early diagnosis and abbreviates the diagnostic delay time in patients presenting with appropriate clinical symptoms. But it should be kept in mind that subchondral bone marrow edema on MRI is not specific evidence for axSpAsince it can be seen in $23 \%$ of those with mechanical low back pain and in $7 \%$ of healthy volunteers [14]. Mild inflammatory changes may also be seen in healthy athletes. Today, although MRI is the most sensitive imaging determiner, another important point is that positive MRI findings alone can result in overdiagnosis of axSpA [15]. Because of the high cost, sacroiliitis on MRI should not be an entry screening method. Especially for appropriately selected patients presenting with inflammatory back pain and without findings of sacroilitis on plain $\mathrm{x}$-ray as in our study, many of them may be diagnosed at an early, non-radiographic state of disease using combined MRI and ASAS criteria [16]. Another point is that performing MRI is a relatively new imaging method for diagnosis of axSpA. Disease duration was higher in AS patients in our study. Limited possibilities of MRI examinations in the early 2000s may have contributed to diagnostic delay in AS patients.

In a cohort study involving 755 axSpA patients, the AS group showed male dominance, higher mean age, higher inflammatory markers and more frequent radiographic damage compared to nr-axSpA [17]. Also Clementina Medina et al. reported longer disease duration, longer time to diagnosis, higher CRP levels and higher BASDAI values to be more common in AS patients compared to $\mathrm{nr}$-axSpA, and each poses a risk of structural damage [18]. All of the above findings correlated with the findings of our study. Extraarticular manifestations occur in 25-35\% of axSpA patients [1]. In our study there was no significant difference between the two subgroups in terms of the frequency of inflammatory bowel disease, but the frequency of uveitis $[7.9 \%, 0 \%$; p:0.028] was significantly higher in patients with AS than nr-axSpA patients. This condition may be related to the longer disease duration. Hip involvement has been demonstrated in $25-35 \%$ of patients with AS, associated with greater functional limitation and worse prognosis, but has not been studied in nr-axSpA patients. It has been reported that it is more common in patients with early onset AS, and with axial and entheseal disease [19]. In our study, hip involvement was detected in $13.2 \%$ of patients with AS, but was not detected in the nr-axSpA group [13.2\%, 0\%; p:0.005]. Positive HLA B-27 and high CRP are the most commonly used laboratory biomarkers for axSpA. HLA B-27 positivity in nr-axSpA and AS groups was $77 \%$ and $78 \%$, respectively [7]. Imke Redeker et al. stated that among 1677 patients with axSpA, HLA B-27 negativity was a risk factor for longer diagnostic delay time [20]. In our study HLA B-27 was not studied in one third of AS patients. Also, this condition may be one of the causative factors for diagnostic delay. It was stated that both AS and nr-axSpA had comparable burden of disease and treatment modalities [18]. But the result drawn from our study is that use of anti-tumor necrosis factor (anti-TNF) agents was significantly higher in patients with AS, whereas NSAIDs were sufficient for approximately half of patients in the nr-axSpA group.

Various referral strategies have been developed for early diagnosis. The vast majority of them include one or more typical spondyloarthritis features in addition to inflammatory back pain for $>3$ months and age of onset $<45$ as entry criteria. Using these candidate parameters, about $35-45 \%$ of patients were diagnosed early with axSpA [21]. In a PROSpA study, 751 patients had inflammatory back pain (IBP) beginning at an age of $<45$ years. The presence of 1 of 3 criteria, including HLA B-27 positivity, current IBP and MRI evidence, is effective for early diagnosis in $46 \%$ of patients with axSpA [22]. A combination of AWARE criteria indicative for IBP and positive imaging or HLA B-27 positivity also benefits in the early detection 
of patients with axSpA [23]. ASAS and Brandt I strategies are the most sensitive $(98 \%)$ but have low specificity (18\% and $11 \%$, respectively). According to Brandt I strategies, patients are referred to a rheumatologist if HLA B-27 positivity and/or IBP is present [24]. The conclusion drawn from the above studies is that inflammatory back pain is the most important entry criteria for referral. Although all of the patients in our study had inflammatory back pain initially, more than half of them were considered to have fibromyalgia. So the differences between inflammatory and mechanical back pain should be precisely explained to health care professionals who first meet patients. HLA B27 positivity and positive MR imaging, as in our study, and extra-articular clinical manifestations may have a contributory effect in referring patients to appropriate specialists. Patients with acute anterior uveitis, inflammatory bowel disease and psoriasis may be target populations [6]. Therefore, specialists including ophthalmologists, gastroenterologists and dermatologists who manage extraarticular manifestations of axSpA may be good sources for patient referral.

Our study had a few limitations that should be noted. One of the major limitations was that it was a retrospective study. The other limitation of our study was related to patient groups. The sample size in the nr-axSpA group was small and the patient groups were non-homogeneous, especially for HLA B-27. Another point is that although the same rheumatologist analyzed all files of each patient including anamnesis, physical examination notes, imaging and laboratory results, all of the patients initially were evaluated by different rheumatologists at their outpatient visits. This study was also a single center experience. The patient images were evaluated by the same experienced rheumatologist. We think that it is not a major problem in clinical practice since rheumatologists are highly experienced in interpretation of radiological images of SIJs.

Today it is well known that early diagnosis and timely treatment improve symptoms and function among young adults with axSpA. As a result of diagnostic delay, patients more commonly experience functional limitations and disability. We must work to increase awareness among nonrheumatologist healthcare providers. Therefore, education of referring providers is very important. Also, validated referral strategies are necessary for selected patients in our country.

\section{CONCLUSION}

The vast majority of patients were initially evaluated by healthcare providers other than rheumatologists and mostly diagnosed with fibromyalgia. Efforts to increase awareness and to educate first healthcare providers may shorten the diagnostic delay time.

Introducere. Un număr crescut de studii au fost realizate la pacienții cu spondilită anchilozantă (AS) şi spondilartropatie axială nonradiologică (nr-axSpA). Scopul studiului a fost de a compara întârzierea diagnostică la pacienții cu As comparativ cu cei cu nr-axSpA.

Metode. A fost realizat un studiu retrospectiv pe 266 de pacienți cu axSpA. Pacienții au fost clasificați în 2 grupe AS și nr-asSpA. Intârzierea diagnosticului $s-a$ referit la timpul de la debutul durerii lombare și diagnosticarea axSpA. Specialitatea mdicului la care pacientul s-a prezentat inițial și primul diagnostic primit de către pacient au fost luate în considerare. Au fost comparate și alte date clinice și paraclinice între cele două grupuri.

Rezultate. Intârzierea diagnosticului a fost semnificativ mai mare la pacientii cu AS (6 \pm 8.14 ani vs $1.62 \pm 2.54$ ani). 40.9\% dintre pacienți au fost consultați inițial de medici cu specialitatea de recuperare medicală. $29.7 \%$ au fost consultați de neurochirurg și $19.9 \%$ de către reumatologi. Cel mai frecvent diagnostic inițial a fost fibromialgia (140 pacienți, 52.6\%) urmat de AS (77 pacienți, 28.9\%) și hernie de disc (34 pacienți, 12.7\%).

Concluzii. Majoritatea pacienților nu au fost inițial evaluați de reumatologi și diagnosticul pus cel mai frecvent a fost de fibromialgie. Trebuie realizate eforturi astfel încât să se scurteze timpul până la corecta diagnosticare a axSpA. 
Correspondence to: Firdevs Ulutaş, MD, Division of Rheumatology, Department of Internal Medicine, Pamukkale University Faculty of Medicine, Denizli, Turkey, E-mail: firdevsulutas1014@gmail.com, Tel: 05300944632

Conflict of interest disclosure: The author delcare no conflict of interest.

Author contributions: All of the authors contributed to this paper and are in agreement with the content of the manuscript. VÇ designed the analysis, FU wrote the paper, HŞ performed data analysis and the other authors contributed data and analysis tools.

Acknowledgements: None to report.

\section{REFERENCES}

1. STOLWIJK C, VAN ONNA M, BOONEN A, TUBERGEN A. Global prevalence of spondyloarthritis: a systematic review and meta-regression analysis. Arthritis Care Res. 2016;68(9):1320-31.

2. KOUGKAS N, AUGOUSTIDIS N, REPA A, BERTSIAS G, ESKITZIS A, SIDIROPOULOS P. The value of the 2011 ASAS classification criteria in patients with Spondyloarthritis and the prognosis of non-radiographic axial Spondyloarthritis: data from a large cohort of a tertiary referral hospital. Mediterr J Rheumatol. 2019;30(1):51-3.

3. COSTANTINO F, ZEBOULON N, SAID-NAHAL R, BREBAN M. Radiographic sacroiliitis develops predictably over time in a cohort of familial spondyloarthritis followed longitudinally. Rheumatology (Oxford). 2017;56(5):811-7.

4. PROTOPOPOV M, PODDUBNYY D. Radiographic progression in non-radiographic axial spondyloarthritis. Expert Rev Clin Immunol. 2018;14(6):525-33.

5. MALAVIYA AP, OSTOR AJ. Early diagnosis crucial in Ankylosing Spondylitis. Practitioner. 2011;255(1746):21-4.

6. KILTZ U, BARALIAKOS X, KARAKOSTAS P, IGELMANN M, KALTHOFF L, KLINK C., et al. Do patients with non-radiographic axial spondylarthritis differ from patients with ankylosing spondylitis? Arthritis Care Res (Hoboken). 2012;64:1415-22.

7. RUDWALEIT M, LANDEWE R, VAN DER HEIJDE D, LISTING J, BRANDT J, BRAUN J, et al. The development of Assessment of Spondylo Arthritis international Society classification criteria for axial spondyloarthritis: classification of paper patients by expert opinion including uncertainty approisal. Ann Rheum Dis 2009;68(6):770-6.

8. H S GOİE THE, M M STEVEN, S M VAN DER LINDEN, A CATS. Evaluation of diagnostic criteria for ankylosing spondylitis: a comparison of the Rome, New York and modified New York criteria in patients with a positive clinical history screening test for ankylosing spondylitis. Br J Rheumatol. 1985;24(3):242-9.

9. JUAN C RUEDA, SOFIA ARIAAS-CORREAL, ANDRES Y VASQUEZ, ENRİQUE CALVO, PAOLA PEÑA, MARLON PORRAS, et al. Interobserver Agreement in Magnetic Resonance of the Sacroiliac Joints in Patients with Spondyloarthritis. Int J Rheumatol. 2017;2017:3143069.

10. DEODHAR A, MITTAL M, REILLY P, BAO Y, MANTHENA S, ANDERSON J, et al. Ankylosing spondylitis diagnosis in US patients with back pain: identifying providers involved and factors associated with rheumatology referral delay. Clin Rheumatol. 2016;35:1769-76.

11. VEDAT G, SERVET A, DILEK S, YAVUZ P, AHMET M O, BUNYAMIN K, et al. Initial Diagnosis of Lumbar Disc Herniation is Associated with a delay in Diagnosis of Ankylosing Spondylitis. J Rheumatol. 2012;39:1996-9.

12. BOYER GS, TEMPLIN DW, BOWLER A, LAWRENCE R C, EVERETT D F, HEYSES P, et al. A comparison of patients with SpA seen in specialty clinics with those identified in a community wide epidemiologic study. Arch Intern Med. 1997;157(18):2111-7.

13. SHMAGEL A, FOLEY R, IBRAHIM H. Epidemiology of chronic low back pain in US adults: data from the 2009-2010 National Health and Nutrition Examination Survey. Arthritis Care Res. 2016;68:1688-94.

14. DANVE A, O'DELL J. The ongoing quest for biomarkers in ankylosing spondylitis. Int J Rheum Dis. 2015;18:826-34.

15. ARNBAK B, GRETHEJURIK A, HORSLEV PETERSEN K, HENDRICKS O, HERMANSEN L T, LOFT A G,et al. Associations between spondyloarthritis features and magnetic resonance imaging findings: A cross-sectional analysis of 1,020 patients with persistent low back pain. Arthritis Rheumatol. 2016;68(4):892-900.

16. MANDL P, NAVARRO-COMPAN V, TERSLOW L, P AEGERTER, D VAN DER HEIJDE, M A D'AGOSTINO, et al. EULAR recommendations for the use of imaging in the diagnosis and management of spondyloarthritis in clinical practice. Ann Rheum Dis. 2015;74(7):1327-39.

17. SIZHENG STEVEN ZHAO, JOERG ERMANN, CHANG XU, CHANG XU, HOUCHEN LYU, SARA K TEDESCHİ, KATHERINE P LIAO, et al. Comparison of comorbidities and treatment between ankylosing spondylitis and non-radiographic axial spondyloarthritis in the United States. Rheumatology 2019;58(11):2025-30.

18. CLEMENTINA MEDINA, SOFIA RAMIRO, DESIREE VAN DER HEIJDE, JOACHIM SIEPER, MAXIME DOUGADOS, ANNA MOLTO. Characteristics and burden of disease in patients with radiographic and non-radiographic axial Spondyloarthritis: a comparison by systematic literature review and meta-analysis. RMD Open. 2019;5:e001108.

19. VANDER CRUYSSEN B, MUÑOZ-GOMARIZ E, FONT P, JUAN M, KURT DE V, ANNELIES B, et al. Hip involvement in ankylosing spondylitis: epidemiology and risk factors associated with hip replacement surgery. Rheumatology (Oxford) 2010;49(1):73-81. 
20. İMKEREDEKER, JOHANNA CALLHOFF, FALK HOFFMANN, HILDRUN HAİBEL, JOACHIM SİEPER, ANGELA ZINK, et al. Determinants of diagnostic delay in axial spondyloarthritis: an analysis based on linked claims and patientreported survey data. Rheumatology (Oxford) 2019;58(9):1634-38.

21. ABHIJEET DANVE, ATUL DEODLAR. Screening and referral for axial spondyloarthritis-need of the hour. Clin Rheumatol. 2015;34:987-993.

22. DEODHAR A, MEASE PJ, REVEILLE JD, JEFFREY R CURTIS, SU CHEN, KAİLASH MALHOTRA, et al. Frequency axial spondyloarthritis diagnosis among patients seen by US rheumatologists for evaluation of chronic back pain. Arthritis Rheumatol. 2016;68(7):1669-76.

23. BRAUN J, MOSCH T, FISCHER I, KILTZ U. Identification of patients with axial spondylarthritis in primary care (AWARE study). Z Rheumatol. 2019;78:569-76.

24. OZAIR ABAWI, ROSALINE VAN DEN BERG, DESIREE VAN DEN HEIJDE, VAN GALEEN F. Evaluation of multiple referral strategies for axial spondyloarthritis in the SPondylo Arthritis Caught Early (SPACE) cohort. RMD open. 2017;3:e00389.

Received 22nd August 2020. 